\title{
Studi Analisis Isi Pesan Dakwah Dalam Media Sosial Instagram@dakwah_tauhid
}

\author{
Agus Triyono, Nifsya Khaira Marhuda \\ Prodi Ilmu Komunikasi \\ Universitas Muhammadiyah Surakarta, Indonesia \\ email: agus.triyono@ums.ac.id ; nifsya@nifa-persada.com
}

\begin{abstract}
The Internet spiritualization means that the internet is seen as a technology or space suitable for religious relationships, allowed user to integrate internet based activities into their spiritual life. This research is aimed to find out the content of da'wah message from posted on salafi @dakwah_tauhid account in instagram. The research method used is quantitative, the data analysis model using content analysis and data types used as a reference in this study is primary data consisting of messages on Instagram@dakwah_tauhid account about aqidah, syariah, and akhlak that have been posted in April 2017. The results of this study indicate that syariah category is the most widely post (140 posts) with a percentage of $49.65 \%$. Aqidah category there are 34 posts with $12.05 \%$ percentage. While the akhlaq category is posting at least that there are only 4 posts with a percentage of $1.4 \%$ of the total post. Syariah category is the most frequent post because in April of 2017 it was a election of regional head of Jakarta, where one of the candidates from the governor of Jakarta is not Muslim. The other category is a category that does not belong to the above three categories but has a large number of posts with 104 posts or $36.9 \%$ of the total population. This is because of the many postings of @ dakwah_tauhid account which contains questions from the admin, study invitations, and the news that is a has trending topic in the society.
\end{abstract}

Keywords: instagram, communication of Da'wah, tinternet and religion

\begin{abstract}
ABSTRAK
Spiritualisasi internet berarti bahwa internet tersebut dilihat sebagai teknologi atau space yang cocok untuk hubungan religious, dimana hal ini mengijinkan pengguna untuk menyatukan aktifitas berbasis internet kedalam ritme kehidupan spiritual mereka. Penelitian ini bertujuan untuk mengetahui bagaimana isi pesan dakwah dari postingan akun salafi @dakwah_tauhid dalam intagram. Metode yang digunakan dalam penelitian ini merupakan metode kuantitatif yang bersifat ex post facto. Adapun model analisis data berupa analisis isi. Jenis data yang dijadikan acuan dalam penelitian ini berupa data primer yang terdiri dari pesan-pesan akun Instagram @dakwah_tauhid tentang aqidah, syariah, dan akhlak yang telah diposting pada bulan April 2017. Hasil dari penelitian ini menunjukkan kategori syariah merupakan postingan terbanyak yaitu 140 postingan dengan prosentase 49,65\%. Kategori aqidah terdapat 34 postingan dengan prosentase 12,05\%. Sedangakan kategori akhlak merupakan postingan paling sedikit yaitu hanya terdapat 4 postingan saja dengan prosentase $1,4 \%$ dari total keseluruhan postingan. Kategori syariah merupakan postingan yang paling sering muncul dikarnakan pada bulan April tersebut bertepatan dengan adanya pilkada serentak dimana salah satu kandidat calon gubernur Jakarta merupakan calon yang bukan beragama Islam. Adapun kategori lain-lain dimana kategori ini bukan termasuk dari tiga kategori diatas tetapi memiliki jumlah postingan yang besar dengan 104 postingan atau 36,9\% dari total populasi. Hal ini dikarnakan banyaknya postingan dari akun@dakwah_tauhid yang berisi tentang pertanyaanpertanyaan dari admin, undangan kajian, juga berita yang sedang hangat di masyarakat.
\end{abstract}

Kata kunci: instagram, komunikasi dakwah, hubungan teknologi dan agama 



\section{Pendahuluan}

Kemajuan Teknologi khususnya internet memudahkan masyarakat untuk mencari segala sesuatu yang diinginkannya, sehingga menjadikan masyarakat sebagai pengguna aktif internet. Internet sendiri merupakan sistem global jaringan komputer yang saling berhubungan yang menggunakan standar Internet Protocol Suite (TCP/IP) untuk melayani miliaran pengguna di seluruh dunia yang merupakan jaringan dari jaringan yang terdiri dari jutaan pribadi, umum, akademik, bisnis, dan jaringan pemerintah, dari lokal untuk lingkup global. Internet membawa berbagai macam sumber informasi dan layanan, seperti antar-linked hypertext dokumen dari World Wide Web (WWW) dan infrastruktur untuk mendukung surat elektronik (Riska, 2013).

Banyaknya manfaat dan kemudahan yang bisa didapat dari internet membuat penggunanya semakin banyak dan bertambah setiap tahunnya. Menurut (APJII) Asosiasi Penyelenggara Jasa Internet Indonesia jumlah pengguna internet pada tahun 2014 sebesar 88,1 juta atau $34,9 \%$ dari 252,4 juta penduduk Indonesia. Chaffey (2016) dalam Global social media research summary 2016 menunjukkan bahwa jumlah pengguna aktif internet dari Januari 2015 hingga
Januari 2016 mengalami peningkatan sebanyak $12 \%$ atau berkisar jumlah pengguna aktif internet di dunia bertambah sebanyak 199 juta orang.

Penggunaan dan pemanfaatan internet dari masing-masing pengguna sangat berbeda-beda. Sebagian dari mereka ada yang menggunakannya untuk mencari edukasi, hiburan, sebagai alat jual beli ataupun menggunakannya untuk manfaat lainnya yang bisa didapatkan dalam internet. Selain itu, banyak juga dari mereka yang menggunakan internet untuk kegiatan spiritual keagamaan sehingga muncul istilah Spiritualisasi Internet.

Spiritualisasi internet berarti bahwa internet tersebut dilihat sebagai teknologi atau space yang cocok untuk hubungan religious, dimana hal ini mengijinkan pengguna untuk menyatukan aktifitas berbasis internet kedalam ritme kehidupan spiritual mereka (Campbell, 2005). Campbell (2005) menjelaskan mengenai proses spiritualisasi internet, dimana terdapat empat kegunaan internet dalam kegiatan keagamaan, yaitu sebagai media spiritual yang memfasilitasi pengalaman spiritual, sebagai ruang sakramental (ruang ibadah), sebagai alat untuk penyebaran agama, dan sebagai teknologi untuk menegaskan identitas keagamaan.

Dawson dan Cowan (dalam Campbell, 2005) menjelaskan berdasarkan 
konferensi internasional pertama di tahun 2001 tentang agama dan internet yang diadakan di Universitas Kopenhagen, Denmark. Religious Encounters in Digital Networks membawa peneliti dari berbagai belahan dunia untuk berdiskusi mengenai penelitian mereka tentang agama di dunia maya. Dalam konferensi tersebut muncul kesimpulan yang menguraikan bahwa organizer konferensi membuat undangan untuk riset yang lebih serius dan refleksi pada kemunculan religiusitas dan ritual dunia maya. Sejak saat itu beberapa naskah telah dipublikasikan yang berakar dari konferensi ini. Hal ini mendemonstrasikan keseriusan yang mana banyak ahli telah mengambil kebutuhan ini untuk investigasi lebih detail pada hubungan religious dunia maya. Dari penjelasan diatas inilah yang membawa peneliti untuk membuat penelitian dengan menggunakan internet dan agama sebagai objek penelitiannya.

Perkembangan teknologi internet saat ini memudahkan para penggunanya untuk mengakses serta menggunakan konten yang ada pada internet. Data dari Kominfo (dalam Ayun, 2015) mengungkapkan bahwa $95 \%$ pengguna internet mengakses jejaring sosial. Sebagaimana yang diketahui, bahwa media sosial merupakan salah satu media online dimana para penggunanya dapat ikut serta dalam mencari informasi, berkomunikasi, dan menjaring pertemanan, dengan segala fasilitas dan aplikasi yang dimilikinya seperti Blog, Facebook, dan Twitter (Setyani, 2013). Seiring berjalannya waktu banyak media sosial baru muncul salah satunya instagram yang dimana menjadi media sosial yang sangat diminati. Indonesia menempatkan diri sebagai pengguna media sosial Instagram ke-3 terbanyak di dunia (Wijaya, 2015).

Menurut Suryani (2014) dalam jurnal Instagram dan Fashion Remaja menjelaskan bahwa media sosial yang saat ini sedang sangat diminati adalah Instagram. Alasan mengapa Instagram berhasil meraih kepopulerannya tak lain karena habbit masyarakat sekarang yang cenderung "narsis". Fitur kamera pada smartphone yang semakin meningkat dari segi kualitas menjadi salah satu penyebabnya. Dimanapun dan kapanpun kita dapat berfoto lalu menguploadnya di Instagram. Bukan hanya foto pribadi dan foto makanan, tempat-tempat umum yang biasanya memiliki daya tarik tidak pernah lepas menjadi sasaran pengguna Instagram untuk difoto. Tidak hanya itu, instagram juga memberikan kesepatan para penggunanya untuk membagi inspirasi dari hasil foto yang bagikan untuk sekedar menyampaikan pesan yang berkaitan dengan foto tersebut atau pengungkapan perasaan penggunanya.

Begitupun para aktivis agama maupun kelompok islam menggunakan 
media ini untuk menyampaikan pesan agama yang mereka pahami. Campbell (2005) menjelaskan bahwa Internet juga mendeskripsikan sebagai alat yang dapat mempromosikan pemberian agama dan praktik religious. Agama dalam hal ini mengacu pada sistem yang terorganisir terkait dengan kepercayaan spiritual. Sehingga agama dapat dengan mudah diterima oleh pengguna internet sebagai media untuk mendapatkan pesan moral yang berkaitan dengan keyakinannya.

Berbeda dengan era modern saat ini, dakwah di dunia offline berkembang menjadi dakwah online. Masyrakat sekarang ini tidak hanya mengandalkan ulama sebagai sumber satu-satunya untuk mendapatkan pengetahuan keagamaan. Internet menjadi media yang mudah dan praktis untuk mencari tahu mengenai persoalan keagamaan (Basit, 2013). Pergeseran ini diikuti oleh para ulama dan organisasi dakwah di Indonesia. Beberapa ustadz dan da'i saat ini juga menggunakan media sosial Instagram untuk berdakwah. Berdasarkan pengamatan awal peneliti per 16 maret 2017, ustadz Yusuf Mansur dengan akun@yusufmansurnew memiliki 1,5 juta pengikut, ustadz Abdullah Gymnastiar dengan akun @aagym memiliki 1,2 juta pengikut, ustadz Felix Siauw dengan akun@felixsiauw memiliki 1 juta pengikut.
Salah satu kelompok agama yang memanfaatkan media sosial instagram sebagai wadah untuk berbagi pesan keagaaman adalah kelompok Salafi. Salafi merupakan salah satu gerakan islam yang tumbuh paling cepat di Indonesia saat ini, yang dimana Indonesia adalah negara muslim non-arab dengan penduduk muslim terbesar di Dunia (Iqbal, 2014). Dalam dakwahnya, ternyata Salafi juga menggunakan media sosial Instagram sebagai media dakwahnya. Hal ini dapat dilihat dari beberapa akun Salafi yang ditemukan peneliti per 16 maret 2017 di Instagram seperti@dakwah_tauhid dengan 451 ribu pengikut, @ salafiyyun dengan 73,6 ribu pengikut, @ dakwahsalafindonesia dengan 67,8 ribu pengikut, dan @thesunnahway_dengan 44,4 ribu pengikut. Peneliti menduga akunakun tersebut merupakan akun Instagram Salafi dimana banyaknya postingan yang membahas tentang ajaran dakwah aqidah salaf dan juga kebanyakan dari postingan akun mencantumkan hastag dakwah_salafi ataupun dakwah_salaf. Peneliti akan mengambil salah satu akun yang memiliki pengikut terbanyak sebagai objek penelitianyaitu@dakwah_tauhid.

Iqbal (2014) meneliti tentang bagaimana Salafi menggunakan internet untuk menunjukan identitas mereka. Penelitian ini dilakukan dengan cara observasi secara online dari web Salafi 
yang dipilih yaitu www.salafy.or.id. Hasil dari penelitian ini menjelaskan bahwa Salafi menggunakan internet untuk menunjukkan identitas mereka dan mempromosikan ideologinya. Salafi juga menggunakan internet sebagai cyberwar untuk memerangi musuh-musuh yang mereka anggap bertentangan dengan ajaran salaf. Relevansi penelitian terdapat pada salafi yang menggunakan internet sebagai media dakwah. Perbedaannya, penelitian yang saya lakukan akan meneliti media sosial instagram yang digunakan salafi.

Penelitian agama dan internet lainnya dilakukan oleh Toybah (2016) dengan judul Dakwah Komunikasi Visual Melalui Instagram Akun @haditsku. Hasil dari penelitian ini menunjukkan bahwa akun instagram @haditsku merupakan akun yang menyebarkan dakwah melalui media sosial. Ada tiga pesan yang terkandung dalam akun tersebut yaitu pesan akidah, pesan ibadah (syariah), dan pesan akhlak. Penelitian ini sama dengan penelitian yang akan saya lakukan, yaitu menganalisis isi dari akun instagram yang telah dipilih. Perbedaannya terdapat pada akun instagram yang dipilih.

Berdasarkan latar belakang yang diuraikan, rumusan masalah penelitian ini adalah bagaimana isi pesan dakwah dari postingan akun salafi @dakwah_tauhid dalam intagram? Penelitian ini diharapkan mampu menjelaskan mengenai bagaimana isi dari postingan dari akun Salafi @dakwah_tauhid.

\section{Metode Penelitian}

Metode yang digunakan dalam penelitian ini merupakan metode kuantitatif yang bersifat ex post facto. Artinya data yang dikumpulkan didapatkan dari kejadian-kejadian yang telah berlangsung. Adapun model analisis data berupa analisis isi. Majhi (2016) mengungkapkan analisis isi adalah seperangkat prosedur yang digunakan untuk mengumpulkan dan mengatur informasi dalam format standar yang memungkinkan analis membuat kesimpulan tentang karakteristik dan makna materi tertulis dan rekaman. Analisis Isi adalah suatu teknik penelitian untuk membuat inferensi-inferensi yang dapat ditiru (replicable) dan data yang sahih dengan memperhatikan konteksnya, serta menggambarkan kecenderungan dari suatu pesan komunikasi (Natasha, 2015). Prosedur dari analisis isi adalah dengan jalan mengukur atau menghitung aspek dari isi (content) dan disajikan secara kuantitaif.

Analisis isi dalam penelitian ini untuk meneliti postingan yang ada dalam akun Instagram @dakwah_tauhid. Jenis data yang dijadikan acuan dalam penelitian ini berupa data primer yang terdiri dari pesan-pesan akun Instagram 
@dakwah_tauhid tentang aqidah, syariah, dan akhlak yang telah diposting pada bulan April 2017 atau bertepatan dengan bulan Rajab $1438 \mathrm{H}$. Alasan mengambil bulan tersebut karena bulan tersebut adalah bulan biasa (bukan hari besar islam atau Ramadhan). Adapun sumber data sekunder yang sifatnya melengkapi data berupa jurnal-jurnal ilmiah, buku-buku, internet, dan sumber data lainnya yang dapat dijadikan sebagai data pelengkap.

Untuk teknik pengumpulan data dalam analisis isi ialah menentukan unit analisis. Krippendorff mendefinisikan unit analisis sebagai apa yang diobservasi, dicatat, dan dianggap sebagai data, memisahkan menurut batasan-batasannya dan mengidentifikasi untuk analisis berikutnya. Unit analisis terbagi ke dalam tiga bagian besar, yakni unit sampel (sampling units), unit pencatatan (recording units), dan unit konteks (context units). Peneliti memberi batasan jelas bahwa yang akan diteliti adalah pesan-pesan akun Instagram @dakwah_tauhid tentang aqidah,syariah dan akhlak. Unit pencatatan adalah unit yang berkaitan dengan bagian apa dari isi yang dicatat, dihitung dan dianalisis. Dalam penelitian ini jenis unit pencatatan yang digunakan adalah unit tematik. Unit tematik secara sederhana meneliti mengenai "teks berbicara tentang apa". Disini peneliti dapat membaca suatu teks (berita dan foto), memberikan penilaian dan mengisi dalam lembar penilaian (lembar coding) yang telah disediakan.

Untuk menghindari bias dalam pengkodingan dan tetap dapat menjaga kredibilitas dan objektivitas penelitian, peneliti dibantu satu orang pengkoder yang meneliti secara terpisah terhadap materi dan objek yang diteliti. Tujuan dari digunakannya satu orang pengkoder adalah untuk memperoleh kesepakatan dan tujuan bersama sehingga diharapkan masukan reliabilitasnya tinggi. Laswell (1989) mengatakan bahwa pemberian angka yang menunjukan kesamaan sebanyak $70 \%$ sampai dengan $80 \%$ antara atau diantara pelaksana koding atau sebuah analisis dapat diterima sebagai kepercayaan yang memadai (dalam Dhanurseto, 2009). Setelah menentukan unit analisis dan membuat kategori, langkah selanjutnya ialah mengisi lembar koding. Lembar koding (coding sheet) adalah alat yang dipakai untuk menghitung atau mengukur aspek tertentu dari isi media. Lembar koding memuat aspek-aspek apa saja yang ingin kita lihat dalam analisis isi.

Penelitian ini menggunakan uji reliabilitas untuk melihat apakah alat ukur dapat dipercaya menghasilkan temuan yang sama, ketika dilakukan oleh orang yang berbeda. Dalam penelitian ini, reliabilitas yang akan peneliti gunakan adalah jenis reproduksibilitas atau yang 
lebih dikenal dengan reliabilitas antarcoder (intercoder reliability) dengan formula presentase persetujuan (percent agreement) formula Holsti (Eriyanto, 2011).

Tabel 1.

Rumus reabilitas formula Holsti

\begin{tabular}{lc}
\hline \multicolumn{1}{c}{ Rumus } & Keterangan \\
\hline Reliabilitas $=$ & Dimana $:$ \\
$\frac{2(\mathrm{M})}{\mathrm{N} 1+\mathrm{N} 2}$ & $N=$ Jumlah Total kategori \\
& $\begin{array}{c}\text { yang dihitung } \\
\text { pengkoder }\end{array}$ \\
& $\begin{array}{c}M=\text { Jumlah Kategori yang } \\
\text { disetujui pengkoder }\end{array}$ \\
\hline
\end{tabular}

Sumber: Eriyanto, 2011

Winarno (2004) menyampaikan bahwa ada beberapa kesepakatan dalam pengujian tersebut, yaitu sebagai berikut:

a. $0 \%-20 \%$, korelasi rendah sekali.

b. $20 \%-40 \%$, korelasi rendah tapi ada.

c. $40 \%-70 \%$, korelasi sedang dan tidak bias.

d. $70 \%-90 \%$, korelasi tinggi.

e. $90 \%$ - $100 \%$, korelasi tinggi sekali

Langkah selanjutnya adalah melakukan input atau rekap data. Hasil analisis isi dapat dideskripsikan dalam bentuk tabulasi tunggal dan tabulasi silang. Tabulasi tunggal digunakan ketika tabel menyajikan data deskripsi dari satu variabel, sedangkan tabulasi silang digunakan ketika tabel menyajikan dua atau lebih variabel.

\section{Hasil Dan Pembahasan}

Akun Instagram @ dakwah_tauhid
Akun dengan nama @dakwah_tauhid adalah salah satu akun dari sekian banyak akun yang konsisten di jalan dakwah. Akun@dakwah_tauhid ini secara rutin setiap harinya memberikan informasi terkait jadwal-jadwal pengajian atau dakwah-dakwah yang dilakukan oleh para ustadz-ustadz sunnah diseluruh daerah. Selain itu akun ini juga selalu menyampaikan pesan-pesan dakwah, baik itu bertemakan tentang tauhid, akhlak maupun syariat. Syiar yang dilakukan beragam bentuknya, mulai dari hasil pengajian berupa vidio atau hasil pengajian berupa tulisan. Tulisan tersebut juga bisa berupa catatan biasa, dan bisa juga tulisan yang disertakan gambar terkait pengajian yang telah dilakukan.

Akun@dakwah_tauhid meyakini bahwa akidah adalah pondasi yang membangun amal-amal ibadah lainnya. Umat Islam tidak pernah berselisih bahwa yang menjadi seruan pertama kali dalam berdakwah adalah ajakan tauhid, yaitu mengajak umat untuk memurnikan ibadah hanya kepada Allah semata. Dakwah tauhid ini juga merupakan inti dari dakwah yang diserukan oleh para nabi dan rasul.

Semenjak dimulainya penelitian ini, peneliti melihat adanya peningkatan yang cukup signifikan dari pengikut akun @dakwah_tauhid. Dimulai dari per 16 maret 2017 akun Instagram @dakwah_tauhid memiliki pengikut 
sebanyak 456.000 pengikut, dan hingga proses penelitian ini berlanjut hingga 14 Desember 2017, pengikut akun @dakwah_tauhid meningkat menjadi 769.000 pengikut dengan 6.179 photo dan vidio yang telah di up load. Adapun penelitian ini hanya menganalisis semua posting akun Instagram@dakwah_tauhid yang dilakukan selama bulan April 2017 yang terkait dengan pesan akidah, pesan (syariah), dan pesan akhlak.

Gambar 1.

Akun@dakwah_tauhid 16 Maret

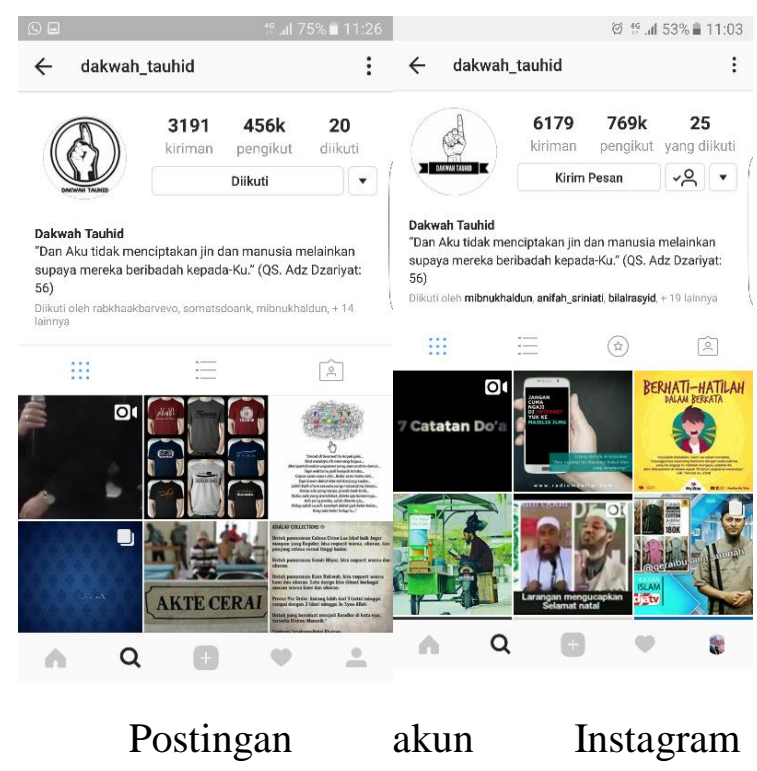

@dakwah_tauhid cukup beragam dan sangat tematik, maka dari itu pada penelitian ini, pengkodingan kategori akun Instagram@dakwah_tauhid menggunakan sistem coding uji tematik, yaitu pengkodingan yang dilakukan dengan mengamati isi dan item dalam setiap postingan yang dilakukan. Karena tujuan dari analisis ini adalah untuk mengetahui isi pesan dakwah dari postingan akun instagram @dakwah_tauhid serta bisa menjelaskan mengenai bagaimana isi dari postingan dari akun Salafi.

Pada penelitian ini, reliabilitas bergerak antara 0 hingga 1 , di mana 0 berarti tidak ada satupun yang disetujui oleh para coder dan 1 berarti persetujuannya sempurna di antara para coder. Makin tinggi angka, makin tinggi pula tingkat reliabilitas. Dalam formula Holsti, angka reliabilitas minimum yang ditoleransi adalah 0,7 atau 70\%. Artinya, kalau hasil perhitungannya menunjukkan angka reliabilitas diatas 0,7 berarti alat ukur ini benar-benar reliabel. Tetapi, jika hasil perhitungan menunjukkan angka dibawah 0,7 berarti alat ukur (coding sheet) bukan alat yang reliabel.

Tabel 2: uji reliabilitas

\begin{tabular}{lcc}
\hline Coder & \multicolumn{2}{c}{ Total Postingan } \\
& \multicolumn{2}{c}{$\mathrm{N}=282$} \\
\cline { 2 - 3 } & Setuju & Tidak setuju \\
\hline
\end{tabular}

$\begin{array}{lll}\text { Coder } 1 & 282 & 0\end{array}$

$\begin{array}{lll}\text { Coder } 2 & 275 & 7\end{array}$

sumber: pengembangan penelitian: 2017

Dari tabel di atas dapat diartikan bahwa berdasarkan rumus:

$\frac{2(M)}{N 1+N 2}=\frac{2(275)}{282+282}=\frac{550}{564}=0,98$

Berdasarkan nilai perhitungan yang mengacu pada hasil pengkodingan, dapat dillihat bahwa untuk semua tema postingan akun Instagram @dakwah_tauhid nilai reliebilitas ada pada angka 0,98 atau $98 \%$. Data ini berarti kesepakatan pengujian 
yang disampaikan sebelumnya dapat dipastikan bahwa kategori uji yang digunakan sangat memadai dan bukan terjadi karena faktor kebetulan.

\section{Kategori Aqidah}

Berdasarkan analisis peneliti terhadap isi postingan akun Instagram @dakwah_tauhid pada bulan April, bahwa semua postingan tersebut menjadi sampel penelitian, dan semua indikator penilaian terhadap fokus studi dibahas dalam akun tersebut. Jika melihat kepada hasil pengkodingan terhadap kategori-kategori tersebut, dapat terlihat bahwa kategori postingan aqidah adalah postingan perkaraperkara yang berkaitan dengan keyakinan terhadap Allah swt dan sifat-sifat kesempurnaanNya.

Secara etimologis kata "aqidah" berasal dari bahasa Arab. "Aqidah" berakar dari kata "aqada-ya"eqidu- "aqdanaqidatan. "Aqdan berarti simpul, ikatan, perjanjian dan kokoh. Setelah terbentuk menjadi Aqidah berarti keyakinan (Munawwir, 1997). Relevansi antara arti kata "aqdan" dan "aqidah" adalah keyakinan itu tersimpul dengan kokoh didalam hati, bersifat mengikat dan mengandung perjanjian (Ilyas, 2011). Dengan demikian dapat dipahami bahwa dalam pengertian umum ,aqidah adalah ilmu yang mengkaji persoalan-persoalan dan eksistensi Allah berikut seluruh unsur yang tercakup didalamnya, suatu kepercayaan kepada Tuhan Yang Maha Esa beserta ajaranNya.

Adapun contoh dari beberapa postingan terkait kategori aqidah ini antara lain postingan tanggal 19 April yang berbunyi "Alhamdulillah sebagian Besar Muslim Indonesia sudah Sadar Dan mau kembali pada Al-Qur'an Dan Sunnah”. Kemudian postingan tanggal 21 April "Kajian Tauhid 'Bahaya Syirik Kecil dan Syirik Besar”. Adalagi postingan tanggal 26 April, "Ajimat berkedok kaligrafi yang menistakan Allah". Kategori postingan aqidah ini berjumlah sebanyak 34 postingan dari total postingan pada bulan April sebanyak 282 postingan.

Selain postingan di atas ada juga beberapa postingan seperti "Bekal yang Sia-sia. Banyak orang yang sudah mengumpulkan bekal untuk akhirat tetapi sia-sia", "Hati yang selamat itu adalah hati yang beriman dengan sebenarnya", "Jangan nikah sama syi'ah", “Imam Ghazali : mencium dan mengusap kuburan adalah amalan orang nasrani dan yahudi”, "Pedoman hidup kita al quran dan hadist .. bukan leluhurmu!.", "Surat Al Jin ayat 6: "Dan bahwasanya ada beberapa orang lakilaki di antara manusia meminta perlindungan kepada beberapa laki-laki di antara jin, maka jin-jin itu menambah bagi mereka dosa dan kesalahan”, "Alhamdulillah sebagian Besar Muslim 
Indonesia sudah Sadar Dan mau kembali pada Al-Qur'an Dan Sunnah". "Syiah bukan Islam. Khomeini membolehkan nikah mut'ah walaupun dengan bayi : Adapun seluruh jenis 'bersenang-senang' seperti menyentuh dengan syahwat, mencium, 'main di paha', maka itu semua tidak mengapa, bahkan untuk anak kecil yang masih menyusu" (Tahrir al-Wasilah, hal 241, no 12)", "Fadhlullah (Syiah) membolehkan memandang para wanita yang sedang telanjang: "Jikalau saja para wanita telah terbiasa keluar rumah dengan pakaian pantai, maka boleh melihat mereka dengan kondisi seperti ini" sampai perkataannya "Dan termasuk bagian ini adalah bolehnya melihat aurat ketika disingkap sendiri oleh wanita tersebut sebagaimana yang terdapat di klub-klub malam, di pinggir pantai di sebagian negara atau semisal itu" (Kitab An-Nikah, Juz 1, hal 66)", kemudan ada beberapa video yang di upload sebagai bagian dari kategori aqidah ini. (lihat lampiran coding)

Tabel 3. Tema Postingan Aqidah

\begin{tabular}{lcc}
\hline \multirow{2}{*}{ Indikator } & \multicolumn{2}{c}{ Tema Postingan Aqidah } \\
& \multicolumn{2}{c}{$\mathrm{N}=34$} \\
\cline { 2 - 3 } Persoalan & Frekuensi & Prosentase \% \\
Akhirat & 4 & 11,8 \\
Keimanan & 16 & 47 \\
Aqidah & 14 & 41,2 \\
\hline sumber: pengembangan penelitian: 2017
\end{tabular}

Keterangan tabel di atas terlihat bahwa untuk kategori aqidah dengan indikator persoalan akhirat terlihat sebanyak 4 kali postingan dengan prosentase $11,8 \%$, kemudian untuk indikator Keimanan terdapat 16 postingan dengan prosentase $47 \%$ dari total postingan dan untuk indikator aqidah itu sendiri terdapat 14 postingan dengan 41,2 $\%$.

\section{Kategori Syariah}

Untuk kategori postingan syariah sesuai lampiran coding yang ada terlihat bahwa kategori ini merupakan kategori yang lebih sering ditayangkan. Meskipun terdapat perbedaan antara coder 1 dengan jumlah 140 postingan dan coder 2 sebanyak 144 postingan. Adapun postingan yang berkatagori syariah adalah semua postingan yang terkait dengan seperangkat norma-norma yang mengatur masalah-masalah bagaimana tata cara beribadah kepada Allah SWT, serta bermuamalah dengan sesama manusia.

Secara istilah "syariat" adalah "Seperangkat norma yang mengatur masalah-masalah bagaimana tata cara beribadah kepada Allah SWT, serta bermuamalah dengan sesama manusia”.

Al-Fairuz Abady menyebutkan bahwa syariat adalah apaapa yang disyariatkan Allah kepada parahamba Nya. (Al-Fairuz Abady: t.th)

Pengertian lain dari syariah juga dijelaskan bahwa syariah berasal dari kata bahasa Arab yang berarti jalan yang harus 
diikuti. Secara harfiah ia berarti "jalan ke sebuah mata air". Ia bukan hanya jalan menuju keridhaan Allah yang Maha Agung, melainkan juga jalan yang diimani oleh seluruh kaum Muslimin sebagai jalan yang dibentangkan oleh Allah, Sang Pencipta itu sendiri, melalui utusan-Nya, Nabi Muhammad SAW. (Abdur Rahman:1991) Secara terminologis, Muhammad Ali al-Sayis mengartikan Syariah dengan jalan "yang lurus". Kemudian pengertian ini dijabarkan menjadi: "Hukum Syara' mengenai perbuatan manusia yang dihasilkan dari dalil-dalil terperinci”. Syekh Mahmud Syaltut mengartikan Syariah sebagai hukum- hukum dan tata aturan yang disyariatkan oleh Allah bagi hamba-Nya untuk diikuti. (Abdur Rahman:2014)

Adapun contoh dari postingan dengan kategori syariah ini adalah postingan pada tanggal 1 April 2017 "Bolehkah berniat mengikuti kajian dengan tujuan agar mendapatkan jodoh yang baik", postingan tanggal 4 April "Allah melaknat orang yang memakan riba, orang yang memberi riba, pencatan dan dua orang saksinya, mereka semua sama. (HR. Bukhori \& Muslim)" postingan tanggal 5 "Riba itu haram.", postingan tanggal 12 April "Baju boleh kotak kotak tapi Gubernur tetap harus pilih yang Muslim Seiman". Postingan tanggal 14 April "Wanita Yang
Diperintahkan Suaminya Untuk Membuka Hijabnya Di Depan Saudara-Saudara Suaminya, Apabila Tidak Demikian Maka Ia Akan Mentalaknya". Contoh lain dari postingan syariah ini seperti; Bolehkah berniat mengikuti kajian dengan tujuan agar mendapatkan jodoh yang baik, Allah melaknat orang yang memakan riba, orang yang memberi riba, pencatan dan dua orang saksinya, mereka semua sama. (HR. Bukhori \& Muslim), Penjelasan Dr. Zakir Naik terkait Surah Al-Maidah ayat 51, Hukum oper kredit KPR, Janji adalah Hutang, Sedekah tidak membuatmu miskin, Muslim tak boleh pilih pemimpin non-Muslim, Riba itu haram, Hukum Isteri Melarang Suami Nikah Lagi (Berpoligami ). Tidak boleh hukumnya seorang isteri melarang suaminya menikah lagi selama belum terjadi perjanjian antara keduanya pada akad nikah. Jika memang disyaratkan, maka sebagaimana sabda Rasulullah Shalallahu "alaihi wa salam," (Kesepakatan) di antara kaum muslimin adalah berdasarkan persyaratan yang mereka ajukan.” (HR.Abu Daud, 3594 dan selainnya), Jangan kau umbar keshalihan dan kemesraan pasanganmu di sosial media, dan masih banyak lagi postingan lainnya dengan total jumlah postingan sebanyak 140 kali. 
Tabel 4.

Tema Postingan Syariah

\begin{tabular}{lcc}
\hline \multicolumn{1}{c}{ Indikator } & \multicolumn{2}{c}{$\begin{array}{c}\text { Tema Postingan Syariah } \\
\text { N=140 }\end{array}$} \\
\hline & Frekuensi & Prosentase \% \\
Hukum dan & 49 & 35 \\
aturan & 21 & 15 \\
Muamalah & 23 & 16,4 \\
Ibadah & 47 & 33,6 \\
Keilmuan & & \\
\hline
\end{tabular}

Dari keterangan tabel di atas terlihat bahwa untuk kategori syariah terdapat 4 indikator yang menjadi potokan dalam penilaian peneliti. Untuk indikator persoalan hukum dan aturan terlihat sebanyak 49 kali postingan dengan prosentase $35 \%$, kemudian untuk indikator muamalah terdapat 21 postingan dengan $15 \%$ dari total postingan dan untuk indikator ibadah terdapat 23 postingan dengan 16,4 serta indikator keilmuan terdapat 47 postingan dengan 33,6 dari totoal postingan syariah.

\section{Kategori Akhlak}

Kategori postingan yang selanjutnya adalah postingan terkait akhlak. Postingan terkait akhlak ini adalah semua postingan yang berisikan tentang semua bentuk tingkah laku, budi pekerti, atau tabi'at yang diperbuat manusia. Dalam pengertian sehari-hari akhlak umumnya disamakan artinya dengan budi pekerti, kesusilaan, sopan santun dalam bahasa Indonesia, dan tidak berbeda pula dengan arti kata moral, ethic dalam bahasa inggris. Manusia akan menjadi sempurna jika mempunyai akhlak terpuji serta menjauhkan segala akhlak tercela.( Mansur: 2009) Secara kebahasaan akhlak bisa baik dan juga bisa buruk, tergantung tata nilai yang dijadikan landasan atau tolok ukurnya. Di Indonesia, kata akhlak selalu berkonotasi positif. Orang yang baik sering disebut orang yang berakhlak, sementara orang yang tidak berlaku baik disebut orang yang tidak berakhlak.

Dari 282 postingan yang dimuat pada bulan Apri 2017 terlihat bahwa postingan terkait akhlak adalah postingan yang paling sedikit jumlahnya, yakni sebanyak 4 postingan. Untuk kategori ini tidak terdapat perbedaan antara peng-coder 1 dan peng-coder 2. Hal ini merupakan sinyalemen bahwa akun instagram @dakwah_tauhid merupakan akun yang lebih menekan pada prihal dakwah tauhid dan syariah. Hal ini juga tercermin pada postingan-postingan akun instagram @dakwah_tauhid pada bulan-bulan sebelumnya.

Adapun contoh-contong postingan yang terkait pesan akhlak dari akun instagram @dakwah_tauhid adalah sebagai berikut: postingan tanggal 6 April "Perubahan Kata Ganti dalam Kalimat "Jazaakallaahu Khairan"”, postingan tanggal 9 April dengan bunyi "Kenapa wanita banyak masuk neraka? "Dan aku melihat neraka. Aku belum pernah sama 
sekali melihat pemandangan seperti hari ini. Dan aku lihat ternyata mayoritas penghuninya adalah para wanita." Mereka bertanya, "Kenapa para wanita menjadi mayoritas penghuni neraka, ya Rasulullah?" Beliau menjawab, "Disebabkan kekufuran mereka." Ada yang bertanya kepada beliau, "Apakah para wanita itu kufur kepada Allah?" Beliau menjawab, “(Tidak, melainkan) mereka kufur kepada suami dan mengkufuri kebaikan (suami). Seandainya engkau berbuat baik kepada salah seorang istri kalian pada suatu waktu, kemudian suatu saat ia melihat darimu ada sesuatu (yang tidak berkenan di hatinya) niscaya ia akan berkata, 'Aku sama sekali belum pernah melihat kebaikan darimu'." (HR. Bukhari no. 5197 dan Muslim no. 907). Kemudian postingan tanggal 12 April "Jaminan rumah di surga bagi mereka yang berakhlak mulia". Kemudian ada juga postingan tanggal 24 April "Agama Islam adalah agama yang benar-benar menghormati hak asasi dan kepemilikan umat manusia. Karenanya Islam tidak membenarkan bagi siapapun untuk mengambil hak seseorang tanpa seizin darinya". Postingan tanggal 25 April "Bagi guru yang masih merokok sebaiknya memilih berhenti merokok atau berhenti menjadi guru, murid perlu teladan yang baik".
Tabel 5:

Tema Postingan Akhlak

\begin{tabular}{lcc}
\hline \multicolumn{1}{c}{ Indikator } & \multicolumn{2}{c}{ Tema Postingan Akhlak } \\
$\mathrm{N}=4$
\end{tabular}

Dari keterangan tabel di atas terlihat bahwa untuk kategori akhlak dengan indikator persoalan ahklak kepada Allah terlihat sebanyak 1 kali postingan dengan prosentase $25 \%$, kemudian untuk indikator ahkalak kepada sesama terdapat 3 postingan dengan $75 \%$ dari total postingan. Selama bulan April, postingan terkait pesan-pesan akhlak ini adalah postingan yang paling sedikit, jumlah postinganya hanya sebanyak 4 kali postingan. Postingan ahklak pada data di atas dapat digambarkan dalam diagram berikut:

\section{Kategori Lain-lain}

Dalam rentang waktu penelitian yang dilakukan yakni selama bulan April, peneliti juga menemukan banyak postingan dari akun instagram @dakwah_tauhid yang memposting informasi-informasi atau dakwah diluar tiga kategori yang menjadi pokok penelitian ini. Dari 282 postingan yang dilakukan pada bulan tersebut terdapat 104 postingan yang merupakan informasi yang peneliti beri nama 
"postingan lain-lain", yakni postingan diluar kategori aqidah, syariah dan akhlak.

Tabel 6.

Tema Postingan lain-lain

\begin{tabular}{lcc}
\hline \multicolumn{1}{c}{ Indikator } & \multicolumn{2}{c}{ Tema Postingan lain-lain } \\
$\mathrm{N}=104$
\end{tabular}

sumber: pengembangan penelitian: 2017

Data yang ada (lihat lampiran coding) terlihat bahwa kedua peng-coder tidak berselisih pendapat terkait jumlah postingan dengan kategori lain-lain ini. Adapun contoh dari postingan dengan kategori lain-lain ini adalah postingan pada tanggal 1 April dimana kedua peng-coder memiliki masing-masing 4 postingan, diantaranya adalah "Setujukah anda jika PPP yang kedua kubunya mendukung penista agama mengganti lambang kakbahnya?"; postingan tanggal 1 April "INFO: Undangan kajian Ust Syafiq di Sragen"; "Jadwal tayangan Live Dr. Zakir Naik" dan "Jin tidak bisa dilihat manusia, Jin bisa dilihat beberapa Hewan”. Tanggal

7 April "INFO : Iklan RBT Dakwah Ustadz Khalid Basalamah". Postingan BERITA : Barusan mendapat kabar bahwa bapak Novel Baswedan akan segera operasi mata pada tanggal 12 April; dan masih banyak lagi postingan yang dikategorikan diluar tema yang telah ditentukan. Selain postingan di atas, juga ada postingan Video : Kajian Ustadz Felix Siauw Dibubarkan Polisi karena desakan ormas tertentu, Info : Undangan Kajian Ansor Day Festival. "Apakah harus seperti ini kajian atau acara ummat islam agar tidak dibubarkan, kemudian video: Surah Ar-Rahman Full Terjemah; Video : Simak penjelasan singkat Ustadz Amni Nur Baits mengenai Paytren berikut ini; Video : Simak penjelasan Ustadz Erwandi Tarmidzi pakar Muamalat Kontemporer berikut ini, dan masih banyak lagi infoinfo serta vidio-vidio yang menjelaskan persoalan-persolan dan informasi berkenaan keislaman lainnya.

Keterangan tabel di atas terlihat bahwa untuk kategori lain-lain ini berisikan berbagai pesan diluar pesan atau kategori yang telah ditetapkan. Adaupun indikator dari postingan-postingan lain-lain ini terdari dari pertanyaan-pertanyaan retoris dari admin @dakwah_tauhid, kemudian info-info yang berkenaan dengan kajian-kajian atau jadwal-jadwal kajian, postingan dengan indikator ini juga disertakan dengan berbagai undanganundangan. Kategori lainnya berupa berita dan pengetahuan seputar agama islam dan pengetahuan umum, dan terakhir postingan dengan kategori vidio yang berisikan kajian dan dakwah yang disapaikan oleh 
ustadz-ustadz dari berbagai kota di Indonesia.

Sejumlah postingan yang telah disebarkan terdapat pesan dengan indikator pertanyaan retoris dan penyataan sebanyak 11 kali postingan atau $10,6 \%$ dari total postingan, kedua postingan dengan kategori info dan undangan dengan total postingan sebanyak 36 kali atau sekitar $34,6 \%$ dari total postingan, kemudian postingan dengan indikator berita dan pengetahuan sebanyak 42 kali postingan atau sebanyak $40,4 \%$ dari total postingan. Dan yang terakhir postingan dengan indikator vidio dengan total postingan sebanyak 16 kali atau sebanyak 15,4\% dari total postingan.

\section{Pembahasan}

Hasil penelitiaan yang telah dijelaskan di atas, penelitian ini hanya meneliti seberapa banyak pesan-pesan dakwah dengan kategori yang telah ditentukan dan diposting pada bulan April 2017. Pemilihan bulan April inipun adalah sudah dipertimbangkan oleh peneliti sebelumnya, karena bulan April 2017 ini merupakan bulan biasa dalam arti kata bukan bulan-bulan besar Islam atau bulanbulan ibadah. Ternyata walaupun bulan April tersebut bukan merupakan bulan besar Islam ataupun bulan ibadah, akun @dakwah_tauhid sangat konsisten dan aktif memberikan banyak postingan dakwah setiap harinya.

Gambar 2.

Prosentase seluruh Kategori

\section{Hasil Kategorisasi}

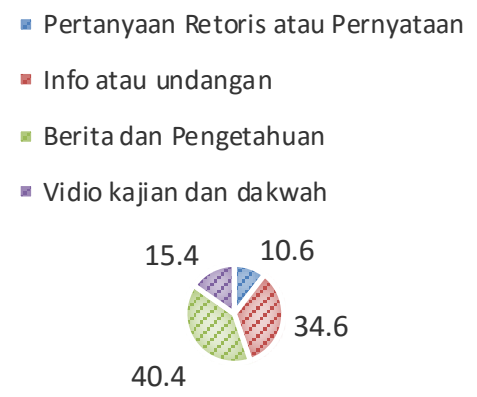

Berdasarkan kategori yang telah ditentukan postingan yang paling terkecil hingga postingan yang paling sering disiarkan terlihat bahwa pesan Akhlak merupakan pesan yang relatif paling sedikit mendapat perhatian akun instagram @ dakwah_tauhid, yakni sebanyak 4 postingan saja. Kemudian untuk kategori selanjutnya adalah kategori Aqidah dengan postingan sebanyak 34 kali postingan. Setelah pesan Aqidah, kategori tentang Syariah adalah postingan atau pesan yang paling sering mendapatkan perhatian admin akun instagram @dakwah_tauhid. Postingan pada kategori syariah ini terdapat sebanyak 140 kali postingan. Kemudian untuk kategori lain-lain yang pada umumnya berisikan berbagai pesan diluar pesan atau kategori yang telah ditetapkan terdapat 104 postingan dalam akun tersebut. 
Banyaknya postingan pada kategori syariah ini tentu tidak terjadi begitu saja, dan peneliti menyimpulkan bahwa banyaknya postingan terkait pesan syariah ini lebih banyak karena dilatarbelakangi pada prosesi perhelatan pilkada Jakarta yang banyak menarik perhatian masyarakat Indonesia kala itu. Tidak terkecuali akun instagram @dakwah_tauhid_yang notabennya adalah akun syiar dakwah, dimana kala itu akun ini lebih banyak menyoroti tentang aturan-aturan Islam terkait pemilihan pemimpin. Dan hal ini terlihat jelas, bahwa pada pesan-pesan yang lebih sering muncul juga mengangkat tentang "keharaman" atau larangan memilih pemimpin "kafir" atau non muslim.

Selain alasan di atas, peneliti juga melihat banyaknya postingan terkait syariah ini karena pada saat yang bersamaan juga banyak beredar issu-issu terkait penyebaran syiah di dunia dan di Indonesia, dan akun instagram @dakwah_tauhid juga tidak ketinggalan yang memberikan pesan dakwah terkait penolakan terhadap golongan syiah ini. Golongan salafi nasional dan multinasional menjadikan internet dalam hal ini media sosial sebagai basis perjuangan mereka. Media informasi dan komunikasi semisal instagram telah membantu melambungkan golongan Salafisme kepada publik untuk menunjukkan sikap ideologis dan doktrinal mereka serta untuk menantang musuhmusuh mereka seperti Jaringan Islam Liberal, Syiah, dan sebagainya. Melalui internet juga, gerakan ini menanggapi isuisu kontemporer seperti terorisme, gempa bumi dan lain-lain (Iqbal, 2014). Dengan banyaknya pesan syariah terkait penolakan terhadap golongan syiah ini menunjukan bahwa akun instagram@dakwah_tauhid cukup konsen melawan "musuh" mereka seperti yang disebutkan Iqbal (2014) dalam jurnalnya. Dimana dalam banyak kajian dan pendapat para mubaligh salafiyah yang beranggapan bahwa kelompok syiahlah yang menyebarkan tentang issu-issu kesesatan kelompok salafiyah dengan jargon "golongan yang memiliki tabiah suka mengkafirkan sesama muslim yang tidak sejalan dengan golongan ini”.

\section{Penutup}

Dalam kajian analisis isi pada penelitian ini, peneliti telah melakukan serangkaian proses untuk melihat bagaimana isi pesan-pesan media yang disampaikan oleh akun instagram dengan nama@dakwah_tauhid. Akun ini merupakan akun dakwah dan kajian keislaman yang memiliki panyak penggemar dan pengikut. Postingan akun Instagram@dakwah_tauhid cukup beragam dan sangat tematik, maka dari itu pada penelitian ini, pengkodingan kategori akun@Instagram @ dakwah_tauhid 
menggunakan sistem coding uji tematik, yaitu pengkodingan yang dilakukan dengan mengamati isi dan item dalam setiap postingan yang dilakukan. Pada penelitian ini, dapat dillihat bahwa untuk semua tema postingan akun Instagram @ dakwah_tauhid nilai reliebilitas ada pada angka 0,98 atau 98\%. Adapun kategori analisis isi yang dilakukan berupa Kategori Aqidah dengan indikator persoalan akhirat terlihat sebanyak 4 kali postingan dengan prosentase 11,8\%, kemudian untuk indikator Keimanan terdapat 16 postingan dengan $47 \%$ dari total postingan dan untuk indikator aqidah itu sendiri terdapat 14 postingan dengan 41,2 \%. Kategori Syariah dengan indikator persoalan hukum dan aturan terlihat sebanyak 49 kali postingan dengan prosentase $35 \%$, kemudian untuk indikator muamalah terdapat 21 postingan dengan $15 \%$ dari total postingan dan untuk indikator ibadah terdapat 23 postingan dengan 16,4 serta indikator keilmuan terdapat 47 postingan dengan 33,6 dari totoal postingan syariah. Kategori Akhlak dengan indikator persoalan ahklak kepada Allah terlihat sebanyak 1 kali postingan dengan prosentase $25 \%$, kemudian untuk indikator ahkalak kepada sesama terdapat 3 postingan dengan $75 \%$ dari total postingan. Selama bulan April, postingan terkait pesan-pesan akhlak ini adalah postingan yang paling sedikit, jumlah postinganya hanya sebanyak 4 kali postingan. Terakhir Kategori Lain-lain dengan indikator pertanyaan retoris dan penyataan sebanyak 11 kali postingan atau $10,6 \%$ dari total postingan, kedua postingan dengan kategori info dan undangan dengan total postingan sebanyak 36 kali atau sekitar $34,6 \%$ dari total postingan, kemudian postingan dengan indikator berita dan pengetahuan sebanyak 42 kali postingan atau sebanyak $40,4 \%$ dari total postingan. Postingan dengan indikator vidio dengan total postingan sebanyak 16 kali atau sebanyak $15,4 \%$ dari total postingan.

\section{Daftar Pustaka}

Andrew F. Hayes \& Klaus Krippendorff 2007 Answering the Call for a Standard Reliability Measure for Coding Data, Communication Methods and Measures, 1:1, 77-89, DOI: $\underline{10.1080 / 19312450709336664}$

APJII. 2015. Profil Pengguna Internet Indonesia 2014. (Puskakom UI Jakarta, Ed.), Apjii.or.Id (1st ed.). Jakarta: Asosiasi Penyelenggara Jasa Internet Indonesia.

Ayun, Primada Qurrota. 2015. Fenomena Remaja Menggunakan Media Sosial dalam Membangun Identitas. Program Studi Ilmu Komunikasi Universitas Ahmad Dahlan Yogyakarta.

Basit, Abdul. 2013. Dakwah Cerdas di Era Modern. Jurnal Komunikasi Islam. 3(1), 76-94.

Campbell, Heidi. 2005. Spiritualising the Internet. Uncovering Discourses and Narratives of Religious Internet 
Usage. Heidelberg Journal of Religions on the Internet, 1(1), 1-22.

Chaffey, D. 2016. Global social media research summary 2016. Retrieved from

http://www.smartinsights.com/soci al-media-marketing/social-mediastrategy/new-global-social-mediaresearch/

Dhanurseto, H. 2009. Pemberitaan Media Cetak Dalam Kampanye Pemilu Presiden Tahun 2009 Studi Analisis Isi Pemberitaan Pemilu Presiden pada masa kampanye di media Cetak Harian Jogja, Radar Jogja dan Kedaulatan Rakyat Jogja Edisi JuniJuli 2009). Jurnal Politik, 5.

Eriyanto. 2011. Analisis Isi : Pengantar Metodologi untuk Penelitian IlmuKomunikasi dan Ilmu-Ilmu Sosial Lainnya. Jakarta: Kencana Prenada Media Group.

Ilyas, Y. 2011. Cakrawala Al Qur'an: tafsir Tematis tentang Berbagai Aspek Kehidupan.

Iqbal, A. M. 2014. Internet, Identity and Islamic Movements: The Case Of Salafism In Indonesia. Islamica Indonesiana, 1(1), 81-99.

Majhi, Sabitri. 2016. Content analysis of Journal articles on Wiki in Science Direct Database. Library Philosophy and Practice (e-journal), 1331

Munawwir.A.W. 1997. Kamus AlMunawwir Arab-Indonesia Terlengkap. Surabaya: Pustaka Progressif

Natasha, Gessa. 2015 Analisis Isi Rubrik "Indonesia Banget" Pada Majalah
Gogirl! Tahun 2013 Tentang Tradisi Di Indonesia. eJournal Ilmu Komunikasi, Volume 3(3), 613-627

Rahman, Abdur. 1991. Inilah Syariah Islam. Jakarta: Pustaka Panji Mas

Riska, Harihanto, \& Nurmanina, A. 2013. Studi Tentang Penggunaan Internet Oleh Pelajar. eJournal SosiatriSosiologi, 1(4), 37-49.

Setyani.N.I. 2013. Penggunaan Media Sosial Sebagai Sarana Komunikasi Bagi Komunitas (Studi Deskriptif Kualitatif Penggunaan Media Sosial Twitter, Facebook, dan Blog sebagai Sarana Komunikasi bagi Komunitas Akademi Berbagi Surakarta). Skripsi. Surakarta. Universitas Negeri Surakarta.

Suryani, L. F., \& Suwarti, H. D. 2014. Instagram Dan Fashion Remaja : Studi Kasus Peran Media Sosial Instagram terhadap Trend Fashion Remaja dalam Akun @ootdindo Tahun 2014. Jurnal Komunikasi.

Toybah, Nur Rizky. 2016. Dakwah Komunikasi Visual Melalui InstagramAkun@haditsku. Institut Agama Islam Negri Antasari.

Winarno,Surakhmad, 1994. "Pengantar Penelitian Ilmiah dasar Metode Teknik", Tarsito, Bandung.

Wijaya, K. K. 2015, Januari 21. Berapa Jumlah Pengguna Website, Mobile, dan Media Sosial di Indonesia. Retrieved from https://id.techinasia.com/laporanpengguna-website-mobile-mediasosial-indonesia. 

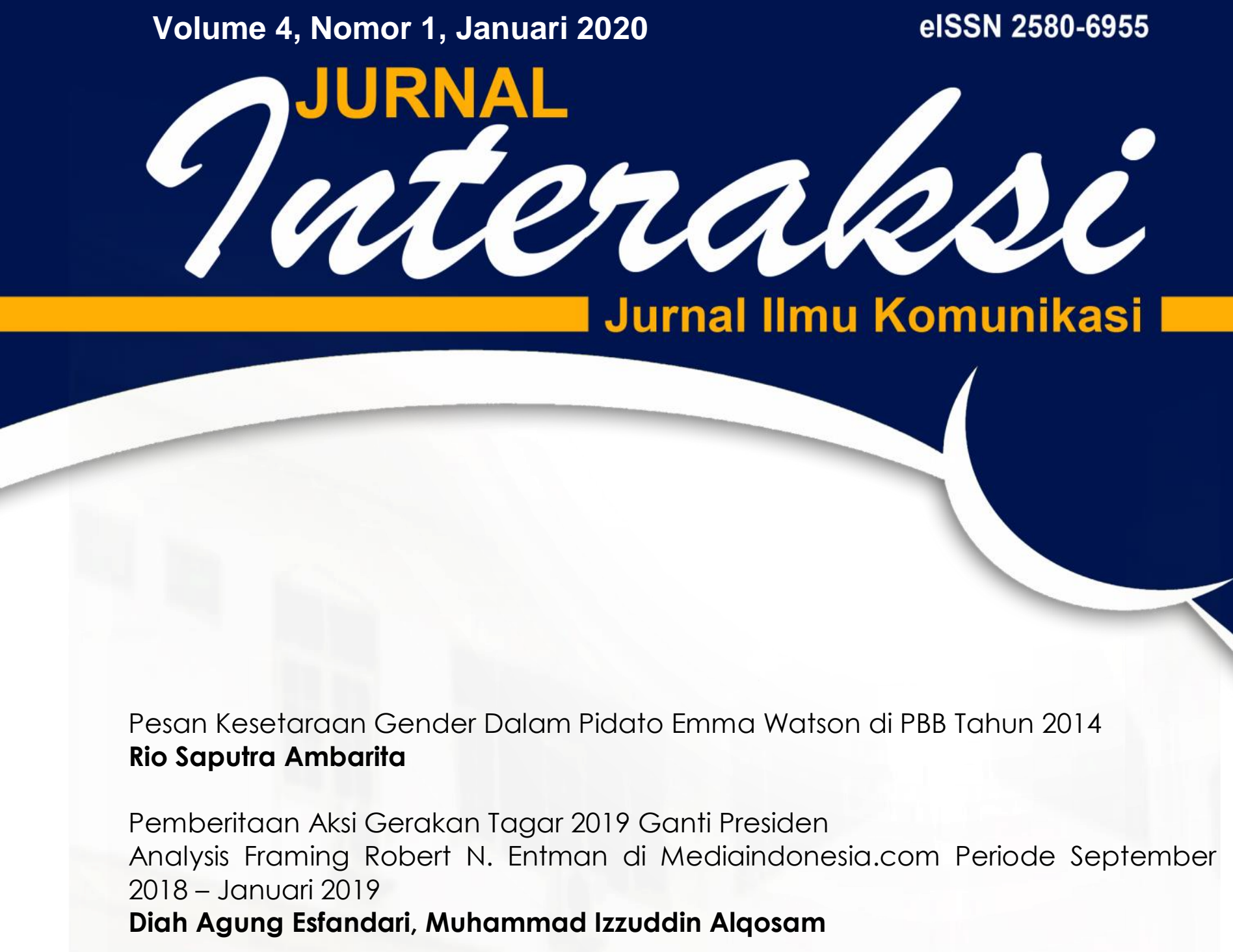

Branding Dan Positioning Identitas Budaya Indonesia Dalam Pesan Iklan TV Komersial Bejo Bintang Toedjoe Jahe Merah

Agus Hermanto, Sa'diah El Adawiyah

Identifikasi Faktor-Faktor Yang Mempengaruhi Minat Berkunjung Ke Olivier Café, Jakarta

\section{Tashia Tariq}

Studi Analisis Isi Pesan Dakwah Dalam Media Sosial Instagram @dakwah_tauhid Agus Triyono, Nifsya Khaira Marhuda

Relasi Politik, Bullying dan Etika Mengenai Isu "Muslim Uighur" di Media sosial Yofiendi Indah Indainanto

Breaking Down "Firewall" among Public Relations and Journalism Jamroji, Nasrullah

Strategi Komunikasi untuk Program Corporate Social Responsibility dalam Pemberdayaan Masyarakat

Arifin Saleh, Mislan Sihite 


\section{Turetralesi Jurnal IImu Komunikasi}

Jurnal Interaksi diterbitkan oleh Universitas Muhammadiyah Sumatera Utara (UMSU) bekerjasama dengan Asosiasi Pendidikan Ilmu Komunikasi Perguruan Tinggi Muhammadiyah (APIK PTM) yang terbit dua kali d alam setahun pada bulan Januari dan Juli. Terbit pertama kali pada bulan Januari 2017.

Jurnal Interaksi memuat tulisan yang difokuskan pada pemikiran kontemporer Ilmu Komunikasi, Media, Teknologi Komunikasi, Komunikasi Terapan, dalam berbagai sudut pandang atau perspektif. 


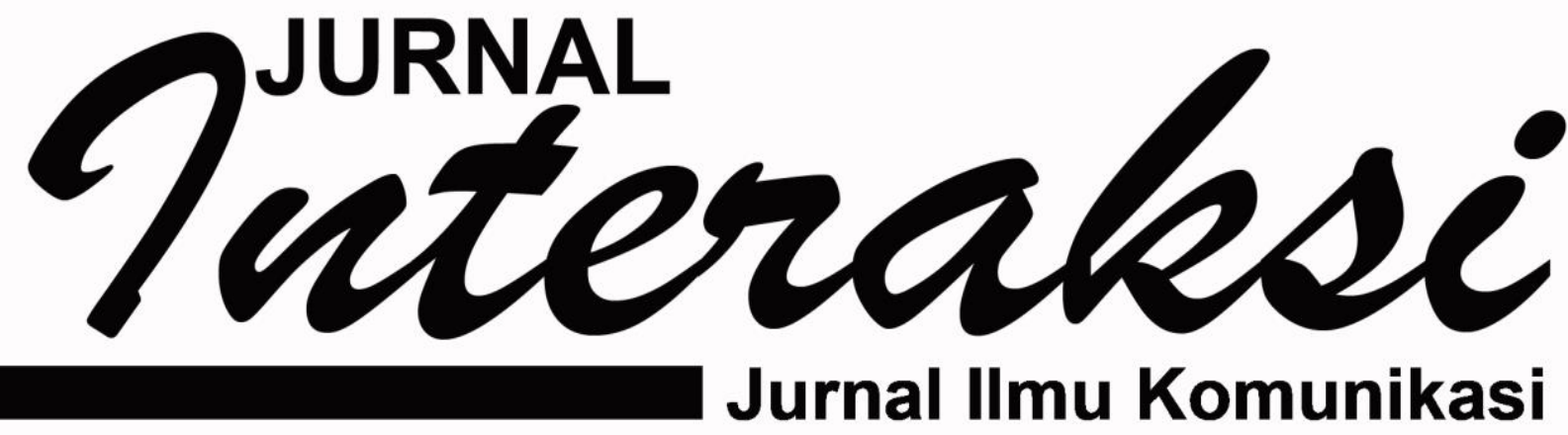

Pesan Kesetaraan Gender Dalam Pidato Emma Watson di PBB Tahun 2014 Rio Saputra Ambarita

Pemberitaan Aksi Gerakan Tagar 2019 Ganti Presiden

Analysis Framing Robert N. Entman di Mediaindonesia.com Periode September 2018 - Januari 2019

Diah Agung Esfandari, Muhammad Izzuddin Alqosam

Branding Dan Positioning Identitas Budaya Indonesia Dalam Pesan Iklan TV Komersial Bejo Bintang Toedjoe Jahe Merah

Agus Hermanto, Sa'diah El Adawiyah

Identifikasi Faktor-Faktor Yang Mempengaruhi Minat Berkunjung Ke Olivier Café, Jakarta

Tashia Tariq

Studi Analisis Isi Pesan Dakwah Dalam Media Sosial Instagram @dakwah_tauhid Agus Triyono, Nifsya Khaira Marhuda

Relasi Politik, Bullying dan Etika Mengenai Isu "Muslim Uighur" di Media sosial Yofiendi Indah Indainanto

Breaking Down "Firewall" among Public Relations and Journalism Jamroji, Nasrullah

Strategi Komunikasi untuk Program Corporate Social Responsibility dalam Pemberdayaan Masyarakat

Arifin Saleh, Mislan Sihite 


\section{Tuteralese}

Volume 4 Nomor 1 Edisi Januari 2020

\section{DAFTAR ISI}

\section{$1-11$}

Pesan Kesetaraan Gender Dalam Pidato Emma Watson di PBB Tahun 2014 Rio Saputra Ambarita

\section{$12-23$}

Pemberitaan Aksi Gerakan Tagar 2019 Ganti Presiden

Analysis Framing Robert N. Entman di Mediaindonesia.com Periode September 2018 - Januari 2019

\section{Diah Agung Esfandari, Muhammad Izzuddin Alqosam}

\section{4-40}

Branding Dan Positioning Identitas Budaya Indonesia Dalam Pesan Iklan TV Komersial Bejo Bintang Toedjoe Jahe Merah

Agus Hermanto, Sa'diah El Adawiyah

\section{1-49}

Identifikasi Faktor-Faktor Yang Mempengaruhi Minat Berkunjung Ke Olivier Café, Jakarta

\section{Tashia Taria}

\section{0-67}

Studi Analisis Isi Pesan Dakwah Dalam Media Sosial Instagram @dakwah_tauhid Agus Triyono, Nifsya Khaira Marhuda

\section{8-85}

Relasi Politik, Bullying dan Etika Mengenai Isu "Muslim Uighur" di Media sosial Yofiendi Indah Indainanto

\section{6-97}

Breaking Down "Firewall" among Public Relations and Journalism Jamroji, Nasrullah

98-105

Strategi Komunikasi untuk Program Corporate Social Responsibility dalam Pemberdayaan Masyarakat

Arifin Saleh, Mislan Sihite 